\title{
What is new in the new industrial policy? A manufacturing systems perspective
}

\author{
Eoin O’Sullivan ${ }^{1}$, Antonio Andreoni, Carlos López-Gómez, and Mike Gregory
}

\begin{abstract}
This paper explores the recent evolution of manufacturing-related policies in leading OECD economiesGermany, Japan, the United Kingdom, and the United States. A novel framework, the industrial policy matrix, is introduced and then used to illustrate and compare policy approaches in terms of factor inputs, intervention levels, and degrees of coordination. While approaches adopted in different countries vary, reflecting their respective contexts, there is some evidence of a convergence on the effectiveness of particular programmes and organizations as well as on the characteristics that support the competitiveness of national manufacturing systems, including coordination and alignment of related policies, partnerships with industry, and longer-term investment and planning.
\end{abstract}

\section{Introduction}

There is renewed interest in 'industrial policy', with a growing number of related articles in the academic literature, national policy debates within leading Organization for Economic Cooperation and Development (OECD) economies, and policy studies by governmental organizations and economic think-tanks. The 2008 financial crisis highlighted the need for new sources of jobs and growth, but policy-makers had already been re-examining industry-related policy approaches, reflecting the changing nature of global manufacturing. These changes include: the declining share of manufacturing activity in OECD countries; growing competition from emerging economies; the growing demands for resource-efficient manufacturing; the increasing complexity and importance of global manufacturing value chains; and finally, the accelerating pace of technological change.

The growing interdependencies between manufacturing value chains and production technologies mean that the competitiveness of national manufacturing-based activities cannot be fully understood by simply analysing data based on traditional industrial or technological classifications. National manufacturing systems involve complex networks contributing a variety of components, materials, production systems and subsystems, and producer services and product-related service systems; all of these are integrated, to varying degrees, within national innovation systems and global value chains. It is in this context that many national governments have been exploring new approaches to strategically strengthen specific sectors, technologies, or particular areas of industrial activity.

This paper explores the recent evolution of manufacturing-related policies in leading OECD economies seeking to identify common themes, patterns, or convergence in policy approaches. We compare recent manufacturing-related policies of four leading advanced economies: Germany, Japan, the UK, and the US - countries with contrasting national manufacturing strengths, industry structures, corporate cultures, and traditions of government intervention. In particular, we attempt to identify, for these countries, policy measures or initiatives which represent recent variations from their traditional approaches to supporting manufacturing-based industrial competitiveness.

\footnotetext{
${ }^{1}$ Corresponding author: Centre for Science, Technology and Innovation Policy, Institute for Manufacturing, University of Cambridge, e-mail: eo252@cam.ac.uk
} 
We have first characterized policy measures in terms of their intended impact on key 'factor inputs' of national manufacturing systems - i.e. measures addressing the nature and availability of: labour, knowledge, natural resources, physical capital, and financial capital - and, then, in terms of their intended system-level impact, i.e. the degree to which they address the competitiveness of particular manufacturing-based firms, manufacturing sectors, cross-sector manufacturing activities, or the wider macroeconomic environment. Focusing on factor-input-related policies rather than the activities of government departments or agencies has enabled a more systematic comparison of national policy approaches of countries with different industry structures, policy agencies, and institutions. We also attempt to identify the extent to which new policies are aligned within coherent industrial strategies. Finally, the division of responsibility for priority-setting and policy implementation between national governments, regional governments, self-governing industrial networks, or regional economic institutions is noted.

The review of changes in manufacturing-related industrial policies is set in the context of recent policy-based analyses of the importance and future of manufacturing and the recent evolution of political and academic discourse(s) on industrial policy itself. Variations in national manufacturing industry strengths and structures, roles of government departments and agencies, as well as supporting industrial networks are described in order to better understand key influences on manufacturing policy choices, priorities, and implementation mechanisms.

Our conclusions suggest that, although countries are exploring new ways to support manufacturing (or ways of putting additional emphasis and funding behind key existing measures), the important changes in manufacturing-related policy vary from country to country, representing distinct national attempts to address perceived challenges to local manufacturing competitiveness and opportunities for industrial growth. There is, however, some convergence of opinion on important features of national manufacturing systems where there is scope for greater policy attention, including: the importance of manufacturing R\&D, increased emphasis on engineering skills and vocational education, and resource-efficient sustainable manufacturing, and-following the 2008 financial crisis-access to finance for manufacturing-based firms. Also, many policy-related analyses emphasize the systemsnature of manufacturing and highlight the strategic role for government in supporting the coordination and alignment of these systems with increasing emphasis on developing strategies in 'partnership' with industry, often in cooperation with industrial associations, to ensure policies are informed by the different elements of national manufacturing systems.

Finally, we argue that the increasing complexity and global integration of national manufacturing systems will require more systematic, coordinated approaches to industrial strategy development and manufacturing policy design. In particular, it is becoming increasingly critical to understand the ways in which national manufacturing systems capture value and factor-input policies can address key challenges and opportunities in response to the changing nature of manufacturing.

\section{The context of 'new' industrial policy}

Over the last two centuries the industrialized countries have adopted a wide spectrum of policies aimed at the structural transformation of their national manufacturing systems (Johnson, 1982; Hall, 1986; Dore,1986; Okimoto, 1989; Amsden, 1989; Wade, 1990; Stiglitz, 1996; Evans, 1995; Chang, 2002; Cimoli et al., 2009; Bianchi and Labory, 2011). Countries' contextual characteristics, defined in terms of their institutions, sectoral composition, manufacturing system configuration, technological structure, and resource endowments, all shape and define the scope of different industrial policy approaches.

There are, however, two key interdependent dynamics taking place that trigger (or simply make possible) policy shifts in each country - structural transformations of the global manufacturing system and debates about policy rationales and the appropriate role of the government. Before identifying policy shifts in individual countries, we therefore provide a snapshot of the global context against which 'new' industrial policy takes place. 


\section{(i) Changes in the global manufacturing system}

The global manufacturing landscape has become increasingly fragmented and complex. Goods are increasingly created in stages_-including raw material extraction, component production, assembly, and customization - that may occur in different locations and countries (Shi and Gregory, 1998; Cattaneo et al., 2010). Each of these stages may involve multi-level interactions between firms from different manufacturing and nonmanufacturing based industrial sectors (Park, 1989; Pilat et al., 2008). Recent decades have seen continuous growth of trade in intermediate inputs, i.e. those that are not consumed but used in further stages of the value chain. Sturgeon and Kawakami (2010) found a 10fold increase of world imports of intermediate goods in the last four decades, measured in constant prices. It has been estimated that intermediate goods now dominate over half of trade flows (Miroudot et al., 2009).

The result has been a reshaping of the global industrial structures in terms of location, governance, and ownership of production (Pilat et al., 2008; Gereffi et al., 2005) with global manufacturing 'centres of gravity' in both production and demand shifting away from developed economies towards emerging, mainly Asian countries. Developing countries' share in world manufactured exports rose from 20.4 per cent in 1992 to 29.4 per cent in 2000 and 39 per cent in 2009 (UNIDO, 2011), with an increase in their share of medium- and high-tech products (UNIDO, 2013). In 2010, for the first time, developing economies absorbed close to half of global FDI inflows (UNCTAD, 2012), while non- OECD countries generated half of the world GDP, measured in purchasing power parity (OECD, 2013). These shifts reflect the relocation not only of production but also of related activities such as R\&D and other professional services. According to some estimates, 90 per cent of all electronics R\&D now takes place in Asia (Ezell and Atkinson, 2011).

Alongside these trends, and the growing global demand for manufactured goods a number of questions are emerging about dwindling natural resources, and the availability of fresh water, as well as adverse climate change, underlining the need to improve the overall efficiency of resource consumption (UNIDO, 2011). A number of market, technical, and business model trends are also expected to reshape global manufacturing in the future (Jovane et al., 2009; Abele and Reinhart, 2011; López-Gómez et al., 2013).

- Market 'pull' factors are expected to drive new market requirements, e.g. increased demand for individualized products and products for the emerging global middle class.

- Emerging technical 'push' developments are redefining the competences required for competitiveness, e.g. the dramatic reduction in manufacturing timescales, advances in nano and biotechnology, new materials, and new production technologies.

- Evolving business models and organizational trends are redefining value-chain structures and the ways firms reach customers and develop and sell their products, e.g. the rise of productservice systems and virtual global production networks.

These dynamics are expected to shape the sources of national competitive advantage and present new challenges and opportunities for firms and countries. National responses to a new global manufacturing landscape are likely to be different, reflecting different industrial configurations that are, in turn, the result of differentiated national social, political, and cultural circumstances (Coe et al., 2008). Sturgeon (2002) contrasts 'hierarchical, captive production networks' in Japan which 'rely on dominant lead firms to coordinate tiers of largely captive suppliers'; 'relational production networks' in Germany, which are 'governed less by the authority of lead firms, and more by social relationships between network actors, especially those based on trust and reputation'; and increasingly 'modular networks' in USA, where supplier firms provide turn-key services to their customers that 'require little support or input beyond design specifications'. Indeed, modern industrial policy-making takes place in a context of increasing competition for the industrial activities with the most 'value capture' potential. Understanding the nature and role of factor inputs available in the national manufacturing system is therefore particularly important. 


\section{(ii) Evolution in the industrial policy debate: old and new rationales}

After the Second World War industrial policy was adopted as one of the main tools for countries' indicative planning. It took many forms, from import substitution to export promotion, from infant industry protection to state ownership of enterprises in strategic sectors or national champions' development (Cimoli et al., 2009). The 'picking winners' approach was grounded in the idea that market failures are pervasive (especially in developing economies) and that governments have to take a role in countries' structural transformation. During the second quarter of the last century, the idea that government failures might be even worse than market failures and structural coordination problems became dominant. During this period the term 'industrial policy' became unfashionable in many countries. However, the success of Japan, Taiwan, South Korea, Singapore, and Hong-Kong, which were adopting a variety of interventionist industrial, trade, and technology policies, helped to open the way to what can be considered the modern debate on industrial policies (Rodrik, 2004; Chang, 2011; Warwick, 2013).

The debate on industrial policy has traditionally focused on two main sets of rationales justifying government intervention, namely market failures and structural coordination problems (Lin, 2012; Andreoni and Scazzieri, 2013). In recent years, the classical industrial policy rationales have been further enriched and partially reformulated within a new understanding of techno-innovation dynamics within the Systems of Innovation framework. The latter pioneered by Freeman (1987), Lundvall (1992), and Nelson (1993) addresses: infrastructural and institutional problems; technological lock-in, path dependency, and transition failures; the quality of linkages and network configuration failures; learning dynamics at the firm, local network, and system levels (Metcalfe, 1995; Edquist, 1997; Malerba, 2002; Klein Woolthuis et al., 2005; Andreoni, 2013). These issues have come to be known as systemic or network failures (Chaminade and Edquist, 2006; Coe et al., 2008; Cimoli et al., 2009; Dodgson et al., 2011; Kuznetsov and Sabel, 2011; Wade, 2012), the existence of which highlights the need to go beyond the firm, sector, and macroeconomy levels in order to reflect broader industrial system dynamics.

\section{The industrial policy matrix: a new taxonomy for mapping countries' industrial policy mix}

The industrial policy matrix developed here reflects the main features of the new industrial policy context and attempts to overcome some limitations of currently available taxonomies. It has three distinctive features (Figure 1).

\section{Levels of policy intervention}

The levels chosen to map policy interventions include the conventional manufacturing firms, manufacturing sectors, and macroeconomic framework, but also cross-sectoral manufacturing-based activities, including all those measures having an impact across multiple sectors and along various supply chains of the national manufacturing system.

\section{Factor inputs of the national manufacturing system}

Even at the same level of policy intervention, policy measures might be more or less selective according to the way in which they affect the productivity of factor inputs (Okimoto, 1989, p. 9). Thus, instead of focusing on their different degrees of selectivity, we distinguish policy measures according to the factor inputs they act upon, namely knowledge (in particular R\&D), labour (including skills and education), production capacity (availability and capacity to use and organize manufacturing machinery, factories, equipment, etc.), resources and infrastructures (in particular support for energy/ resource efficiency), and financial capital. The success of the national manufacturing system also depends on its capacity to interact with global markets and production networks, suggesting an additional category grouping policy measures related to global manufacturing systems and markets.

\section{Policy agenda and key intended changes mapping}


A country's industrial policy agenda can be illustrated by mapping key intended changes in the national manufacturing system and the cluster of policy measures associated with each of them. The way in which these measures are coordinated and aligned over time will significantly influence outcomes. The taxonomy developed here therefore allows for the mapping of single policy measures at each level of policy intervention and according to each factor input.

While this matrix approach offers some advantages, it also has limitations. First, though the mapping is intended to capture changes in policy, existing programmes might be simply 'rebranded as new', and it is difficult to gather reliable information on the scale (budget increases with fresh resources) and forms (different ways of using the same or new resources) of any changes. Second, not all changes in manufacturing-related policies reflect more fundamental changes in the overall industrial policy approach. Specifically, some changes are simply consequences of changes in government administration, reflecting party-political differences; others are driven by nationspecific events and circumstance (e.g. the Japanese earthquake, impact of hydraulic fracturing 'fracking' on US energy supplies). Third, not all new policy initiatives cited in government strategies/policies get fundedalthough proposed by national governments they can ultimately be blocked or scaled back by national parliaments. Finally, although discussed to a certain extent in the country sections, policy initiatives carried out by regional/state/Länder governments have not been reported in the matrix. Nevertheless we believe the approach proposed here might be extended to include these different levels of policymaking.

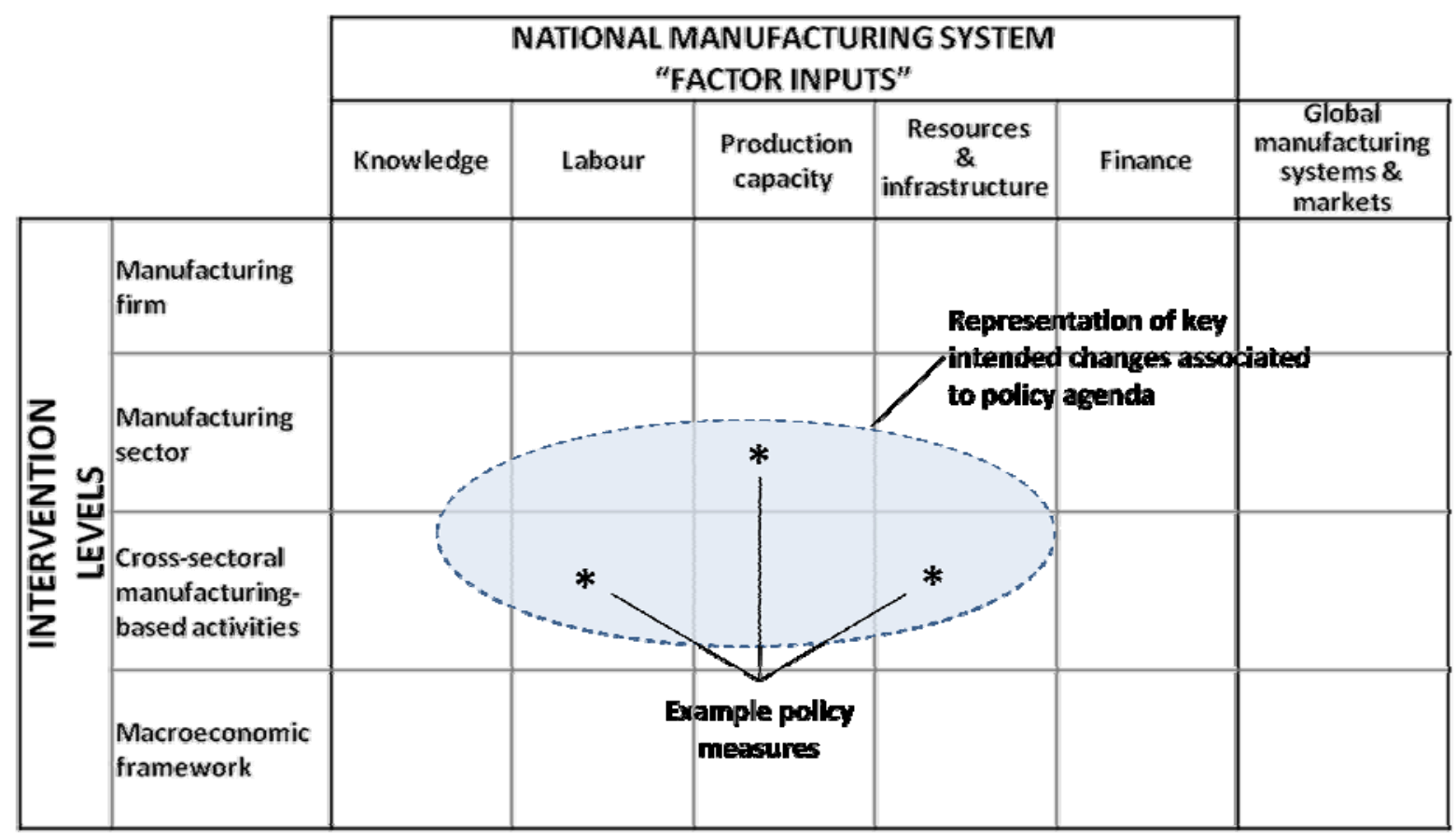

Figure 1: The industrial policy matrix

\section{New industrial policies across OECD countries: United Kingdom, United States, Germany, and Japan}

The four economies reviewed here account for almost half of the world manufacturing value added. In the following country sections the reviews aim to identify key changes in the industrial policy approach, instruments, and delivery as revealed by government official policy documents. For each country a selection of key contextual characteristics affecting industrial policies is presented. The 
closing section highlights the main similarities as well as differences observed across the four countries considered.

\section{(i) The United Kingdom}

Among the countries considered, over the last decades the UK is probably the one which experienced the most profound structural transformation in favour of knowledge-intensive services such as finance, professional services, and information and communications technology (ICT). In 2011 services accounted for a third of total gross value added and a quarter of total employment. Overall their contribution to net exports doubled over the last decade. In 2010 UK commanded almost 18 per cent of world exports in finance, and around 10 per cent of insurance, communications, and cultural and professional services. The contribution of manufacturing to GDP has declined steadily and stood at around 10 per cent in 2011 (BIS, 2012a), though absolute output has remained broadly the same. Substantial manufacturing businesses have moved out of UK ownership-not least ICI, British Oxygen, and Blue Circle Cement, once stalwarts of the UK industrial system.

While the relative scale of UK manufacturing has declined, companies in many sectors remain strong. The aerospace industry is the second largest in the world after that of the US, while automotive car plants register top levels of productivity and the industry has retained high design skills. Vehicles, together with machinery and electrical products, are the main exported goods and account for almost 27 per cent overall. Companies in the chemical and pharmaceutical industry are also internationally competitive, providing a positive net trade balance of almost $£ 7$ billion. Heavy industries, including mining, steel, and shipbuilding, have declined substantially, though the North Sea oil and gas industries continue to do well and are, in fact, experiencing a recent resurgence.

Over the last decade, the UK government became increasingly concerned about the risks associated with over-specialization in services as well as the decline in manufacturing. The recent financial crisis made clear that 'a more diversified economy is less vulnerable to sector specific shocks' (BIS, 2012a, p. 12) and that there was a risk of losing important strategic parts of key high-tech companies such as Rolls Royce, Pfizer, and AstraZeneca. An emerging view in some quarters has been that the economy needs to be rebalanced and that a long-term 'compelling vision' encapsulated in a new industrial strategy was required (Cable, 2012). The formulation of this strategy marked an important change in policy thinking, although traces of this emerging approach can be discerned since the early 2000s.

\section{New policy approach to effect industrial change}

During the 1990s UK policies towards industry were confined mainly to 'horizontal' measures, focusing particularly on education, science, and technology, and on support measures to innovation, entrepreneurship, and business efficiency. The second National Foresight Exercise in 2002 followed by a new Government Manufacturing Strategy presented a 'modern' view of manufacturing as influencing and being influenced by a 'value chain' of activities from R\&D to service, rather than simply the physical conversion of raw materials — and by implication giving manufacturing a more significant economic role. There was, however, very little sectoral focus and very little resource committed. The government sought to reassure industry that manufacturing was taken seriously by establishing a Ministerial Advisory Group on Manufacturing (MAG), involving mainly senior industrialists and representatives of trade unions and broadly representative industry bodies, including the Confederation of British Industry (CBI) and the EEF, the manufacturers' organization, and jointly chaired by a government minister and a leading industrialist. Investments in manufacturing research at around this time were not given high priority, but the establishment of the Technology Strategy Board designed to take science and technology investments out of the direct control of the government and into an arm's length body, with very strong industrial engagement, provided a very practical new vehicle to inform and advise government and to execute programmes on its behalf.

By 2008 the work of the Regional Development Agencies was beginning to have a significant impact through substantial investments in support structures for manufacturing industries including the Centre for Process Industries (CPI) on Teesside, the Advanced Manufacturing Research Centre (AMRC) in Sheffield, and the Manufacturing Technology Centre (MTC) near Coventry. The 
implementation of earlier strategies was to a large extent overtaken by a renewed enthusiasm for the support of key industries by the Department for Business, Innovation and Skills (BIS). Influential documents, including 'New Industries, New Jobs' (HM Government, 2009), led to substantial investments in key industrial sectors. The government also recognized that, despite continuing strong support for university-based science and technology and entrepreneurial initiatives, the translation to the wealth-creating economy was weak.

In 2009 an initiative was set in train to create a network of new Technology Innovation Centres (TICs). The change of government in 2010 led to remarkably little change in policies towards science, technology, and engineering. The TIC initiative was allowed to develop broadly as intended. Catapult Centres, as they were renamed, were established by open competition. The first, in High Value Manufacturing, involved a consortium of seven pre-existing Centres with coordinated funding and supervision. The HVM Catapult is now fully operational and exceeding its original targets. Further Catapults are now being established including Offshore Renewable Energy and Transport Systems.

In 2012 BIS declared a new 'sectoral approach' to industrial strategy (BIS, 2012a) based upon close partnerships between government and industry, involving the establishment of 'leadership groups' of senior industrialists and civil servants in the development of long-term strategies for key sectors. The rationale for this new approach was that long-term investments in the national interest with a degree of risk that could not be expected to be fully funded privately would require public support. Four of these strategies have now been published including Life Science, Energy (Nuclear and Oil and Gas), and Aerospace (HM Government, 2013), the last perhaps most significantly attracting $£ 1$ billion of public funds over 7 years to support research and development related to the industry. The Regional Development Agency system was dismantled and replaced by a new mechanism built around Local Enterprise Partnerships (LEPS), progressively enhanced through opportunities to bid for additional funds for regional growth, cities, and development areas which can remit funds locally. Financial support to industry was seen as a continuing problem, despite exhortations to banks to lend more freely. Arrangements for a new 'Business Bank' were announced, which will involve a new capital allocation of $£ 1$ billion. This new financial infrastructure will be fully operational by 2014, but will start launching investment programmes and attracting private funds during the second half of 2013 (BIS, 2013). Also, new awareness of the importance of using public procurement in a more strategic way was raised (e.g. in tunnelling (BIS, 2012b)).

The evolution of policy over recent years shows a marked trend away from a primary emphasis on a 'horizontal' and regional focus to a more strategic national approach in partnership with industry towards key sectors accompanied by a determined effort through the new Catapult Centres to bring the science base into closer conjunction with industry. In summary, these changes represent a substantial shift in UK government policies towards industry and manufacturing.

\section{(ii) The United States}

The United States is home of the biggest and one of the most sophisticated and diversified industrial systems in the world, currently accounting for roughly one-fourth of global manufacturing value added. In 2010 manufacturing industries generated US\$1.7 trillion in value, or 11.7 per cent of GDP, employed 11.5m workers, and contributed 60 per cent of total exports (Executive Office of the President (EOP), 2012). Throughout the second half of the last century US manufacturing increasingly specialized in science-based and scale-intensive industries such as chemical products, motor vehicles, and transportation equipment, as well as in high-tech industries, such as computer and electronic products. At the same time, food, apparel, wood product, and printing still represent a very significant share in the total manufacturing output (NIST, 2013).

The US innovation system has been among the main drivers of industrial success and, although other countries have aggressively entered the technological race, the US still leads the world in research spending and patenting. Traditionally the innovation system has been articulated around a web of largely publically funded research universities and national laboratories as well as a set of public agencies and departments such as the Department of Defense, the National Institutes of Health, the 
National Science Foundation (NSF), the National Institute for Standards and Technology (NIST), the Departments of Defense, Energy and Agriculture, and finally the National Aeronautics and Space Administration (Fuchs, 2010; O’Sullivan, 2011). Among them, since the mid-1990s, the Department of Defense has increasingly played a major role. Currently it accounts for half of the federal R\&D spending and operates through powerful programmes and agencies such as ManTech and the renowned DARPA. Federal R\&D efforts have been mainly focused on developing technologies in defence, space, health, energy, and environment, or in a selected number of industries through both research grants in response to proposals and public-private partnerships promotion. Currently 75 per cent of the federal $R \& D$ for manufacturing is concentrated in two industries, namely aerospace and instruments (Wessner and Wolff, 2012).

Throughout the second half of the last century, the finance, insurance, real estate, and leasing sector grew much faster than manufacturing. As a result, manufacturing's share of GDP fell significantly, such that today the real estate industry alone is larger than the entire manufacturing industry (NIST, 2013). Almost $8 \mathrm{~m}$ manufacturing jobs have been lost in the last 30 years. However, this relative decline has been accompanied by a profound transformation of the US national manufacturing system. Major US companies have been increasingly offshoring their production plants and, more recently, their R\&D centres. This trend is epitomized by DuPont's strategic R\&D investment in India or by IBM's new R\&D centres in China (Wessner and Wolff, 2012). The offshoring of large-scale manufacturing plants did not simply imply that new technologies and products generated in the US, such as rechargeable lithium-ion batteries, liquid crystal-displays, oxide ceramics, solar cells, and semiconductor memory devices and equipment, were manufactured abroad. It also resulted in a process of production and innovation de-linking that has undermined the innovation capacity of the US economic system, generating phenomena of technological lock-in and industrial commons destructions (Fuchs and Kirchain, 2010; Tassey, 2010; Pisano and Shih, 2012). These dynamics are clearly reflected in the drastic deterioration of the US's trade performances in high-tech products, from strong surpluses in the 1990s to an annual deficit of almost US\$100 billion in 2011. Similarly, there has been a loss of the scale capacity that is necessary to face the competition of Chinese companies, for example in the production of wind turbines and generators or photovoltaic modules. These worrying trends have been coupled by an increasing decline and uncertainty in R\&D public funding since the mid-1980s, as well as a new national crisis in the shortage of skilled workers. It was estimated that some 60 per cent of the science and engineering workforce in US will be eligible for retirement in the next 5 years and that the current production of skills is completely insufficient to match current and future national needs. Indeed, the proportion of students earning degrees in science and engineering is less than 5 per cent, compared to 12 per cent in Europe (mainly in Germany) and over 20 per cent in Asia (Wessner and Wolff, 2012, p. 91).

Over the last two decades, the way in which the US has been tackling these emerging structural challenges has been mainly characterized by a strong emphasis (especially at the federal level) on innovation policies, more than industrial policies as such (Chang et al., 2013). The recent PCAST publication, 'Ensuring American Leadership in Advanced Manufacturing' (EOP and PCAST, 2011), claims that '[w]hile the United States should avoid industrial policy—making bets on particular companies and industries - we should be unabashed in pursuing an innovation policy'. A complicating factor is that the 50 states of the US have been using their autonomy to adopt a large array of more or less selective policy instruments for nurturing the different industries in which they specialize, or, more recently, for supporting fracking research and energyrelated initiatives. At the federal level there is a lack of policy coordination (Ketels, 2007; Di Tommaso and Schweitzer, 2013). Moreover, as a result of the strong division of powers at the federal level, there has been a tendency 'to address specific needs and goals through targeted, short-term legislation and programs that shift from one Administration to the next' (Wessner and Wolff, 2012, p. 53; see also Wade, 2012). Regardless of the composition of Congress or the president in power, the US Administration's industrial policy agenda has been fundamentally focused on: (i) rebuilding framework conditions for US-based manufacturing competitiveness by providing access to skills and finance for small and medium-sized enterprises (SMEs), and by reducing costs faced by companies, such as those related to healthcare, taxes, and energy (US Department of Commerce, 2004; Domestic Policy Council, 2006); 
(ii) the creation of a 'level playing field' and ensuring access to international markets through bilateral agreements and enforcement of World Trade Organization regulations; (iii) boosting advanced manufacturing $R \& D$ by allocating resources for science and technological innovation and supporting special agencies or programmes.

New policy approach to effect industrial change

Over the last decade, it is possible to track a number of ways in which the same policy instruments have been deployed differently. The financial crisis was only partially responsible for this shift, although it stimulated a rethink of the role of the federal state and legitimized market-failure arguments which since then have been increasingly apparent in policy documents (US Congress, 2009; EOP, 2012). The American Recovery and Reinvestment Act (ARRA) of 2009 was a one-time US\$787 billion stimulus package.

Among its measures were bailouts of 'too big to fail' companies such as General Motors being used for their partial restructuring and a massive boost of US\$100 billion for clean-energy initiatives, mixing loan guarantees for renewable energies, electricity transmission projects, and smart grids, but also grants for batteries and key materials and research projects such as those funded by ARPA-E (Advanced Research Projects Agency—Energy). At the state level, New York, Michigan, and Ohio, among others, implemented schemes for facilitating industrial restructuring through $R \& D$ laboratories and parks, attracting investments and establishing new advanced manufacturing hubs, and increasing their investments in fossil energy extraction and fracking research.

After the emergency, the Obama Administration announced significant increases in funding of selected previous administrations' measures as well as a series of new policies acting upon critical factor inputs. In 2010 the 'National Export Initiative' was launched with the aim of creating jobs and growth by doubling exports by 2014. This initiative included promotion of trade missions and foreign trade shows, recruitment of foreign buyers, the creation of an Interagency Trade Enforcement Centre, the financing of the Export Express programme, and, finally, the expansion of credit availability in particular for SMEs and export-oriented firms through the Export-Import Bank and the Small Business Jobs Act. Access to financial capital for SMEs was also increased through other pre-existing programmes. For example, the successful Small Business Innovation Research Program (SBIR) provides more than US $\$ 2.5$ billion annually in the form of R\&D grants and public contracts to small businesses specializing in scaling up and manufacturing highly specific technological systems and components. A number of incentives and programmes were also introduced aimed at rebuilding framework conditions for US-based manufacturing. The Manufacturing Extension Partnership, originally launched by the Bush Administration, was strengthened with a 100 per cent increase in funding. An additional US\$5 billion were invested in the Advanced Energy Manufacturing tax credit. Financial incentives and tax relief for investments in plant and equipment were provided (US Congress, 2011a). Tax deductions for shipping jobs abroad were removed and insourcing was encouraged through a 20 per cent income tax credit. A hundred new science, technology, engineering, and mathematics (STEM)-focused high schools and incentive schemes for increasing STEM graduate rates were launched (US Congress, 2011b). After the promotion of the new Materials Genome Initiative and the Robotics Centre, the Obama Administration also increased its efforts to boost and coordinate manufacturing R\&D. Following recommendations by the President's Council of Advisors on Science and Technology (PCAST, 2012), the Obama Administration proposed investing US\$1 billion in the creation of a National Network for Manufacturing Innovation (NNMI) - a network of regional 'Innovative Manufacturing Institutes' (IMIs) designed to accelerate the development and adoption of advanced manufacturing technologies (OMB, 2012). Following the creation of a pilot IMI for additive manufacturing in 2012, the Obama Administration plans to launch three new institutes in 2013 and has called on Congress to support the creation of up to 45 IMIs over 10 years (White House, 2013).

\section{(iii) Germany}

Manufacturing industry accounts for over a fifth of Germany's value added—one of the highest shares in Europe - and German firms generate over a quarter of EU manufacturing turnover and enjoy 
strong demand overseas. According to UNIDO, Germany is responsible for over a tenth of the world's exports of manufacturing products, a share smaller only than China's. Germany has managed to increase its share of the world market over the last few years.

Manufacturing in Germany spans a broad range of industries with a variety of company sizes and structures. German manufacturing firms are characterized by a high level of productivity and product quality, supported by the country's education, training and research infrastructure, as well as technological advantages in areas such as mechanical engineering, measurement, and control technology (BMWi, 2010). German firms are leaders not only in consumer but also capital goods and industrial durables. In particular, Germany's strength in capital goods is recognized globally and the country was in 2012 the second largest exporter of machine tools, only after Japan (VDW, 2013).

Germany has also emerged as a leader in key new technologies, including renewable energy such as solar and wind power. Power produced from renewable energy sources reached a share of 23 per cent of Germany's gross power consumption at the end of 2012 (GTI, 2013). Germany is the world's biggest photovoltaic (PV) market, housing nearly half of the solar modules in operation worldwide (GTI, 2011). The country was responsible for 75 per cent of European cell production capacity and 60 per cent of European module production capacity in 2010. In terms of wind power, Germany represents around 30 per cent of total installed capacity in Europe and 12 per cent of global installed capacity (GTI, 2013).

Germany is best known internationally for its leading large corporations, including Volkswagen, Daimler, Siemens, Bayer, and BASF. However, it is the small and medium-sized companies-known as the Mittelstand - that constitute the backbone of the country's manufacturing industry. According to official data, they constitute 99.6 per cent of all companies and account for around 70 per cent of all exports and almost 80 per cent of employment. Roughly 95 per cent of the Mittelstand are familyowned, and approximately 85 per cent are managed by their owner (BMWi, 2012). Many of the German Mittelstand are little-known world market leaders in different niches- 'hidden champions'which have specialized in product know-how in terms of both product and application, maintained core manufacturing competences, and developed a global selling and marketing presence (Simon, 2009).

Due, in part, to the strong end-product orientation of the Mittelstand, German production networks are remarkably vertically integrated. This has enabled them to remain largely self-reliant in the market (Sturgeon, 2002). Enabled by a broadly supportive banking sector with strong regional capabilities, German manufacturing firms, both large and Mittelstand, tend to take a particularly long-term approach to business, typically maintaining a high equity ratio and following a cautious approach to expansion (BMWi, 2012). German manufacturing firms have been traditionally supported by a decentralized and complex but highly organized institutional infrastructure at the national and regional levels, including employer associations, unions, universities, and researcher centres. Such institutions are available to firms in practically every industry, and are funded directly or indirectly by the government. Many of them have deep historical roots, and while their functions have been continuously upgraded, they have ensured a relatively stable policy context. Types of assistance available to German firms include the following:

- access to R\&D funding collaboration networks, including those coordinated by the

- German research organizations (e.g. Fraunhofer Society, Helmholtz Association, Max Planck Society, and Leibniz Association), as well as SME-specific programmes, such as those funded by the German Federation of Industrial Research Association (AiF). During the crisis, additional funds were made available to SMEs through mechanisms such as the SME Central Innovation Programme (ZIM);

- $\quad$ vocational training, supported by Germany's dual education system, and coordinated by industry associations and trade unions. Furthermore, student loans are offered by governmentowned banks such as KfW; 
- access to support programmes and practices for improving organizational and technical capabilities, notably through the Fraunhofer Institutes and Steinbeis Centres (see Ezell and Atkinson, 2011);

- $\quad$ stable access to finance, particularly to SMEs, through the government-owned bank KfM as well as a range of savings and cooperative banks;

- $\quad$ foreign trade and investment advice, offered by Germany Trade \& Invest (GTAI), the foreign trade and inward investment agency, and the German Chambers of Commerce (AHKs).

Another distinctive feature in Germany is its multi-layered policy landscape. Besides the states (Länder) and local authorities, European integration has added another layer of political decisionmaking. Though a detailed discussion of these dynamics is outside the scope of this paper, it is important to recognize that many of the institutions listed above interact in varying degrees with the Länder and European institutions.

Despite their leading position globally, German manufacturing firms face increasing competitive pressures from emerging economies in certain industries. Concerns have been raised about the country's potential to sustain future industrial growth due to issues such as excessive dependency on raw materials imports and shortages of skilled workers and engineers (BMWi, 2010).

The potential of manufacturing offshoring/outsourcing to undermine Germany's industry clusters, in both established and emerging industries, has also been recognized (BMBF, 2010). Labour-intensive industries, such as shipbuilding, have declined significantly. Similarly, German PV manufactures have steadily lost market share to Chinese competitors, who have become the major world producers of PV cells. Some German companies in the solar energy industry have filed for bankruptcy over the last few years. In the lithium-ion battery technology race, Korea has outperformed Germany and taken Japan's place as the world leader.

Recently, the government has highlighted the need to protect domestic technological advantages in the face of increased foreign manufacturing investment in Germany (BMBF, 2010). According to the Chinese Ministry of Commerce, Chinese direct investment in Germany doubled from 2007 to 2010, mainly in machinery and equipment, ICT, and renewable energy. The ICT firm Huawei has established 18 branches and six R\&D centres, with more than 1,600 employees.

Growth in emerging economies, however, is also seen as a strategic opportunity for German manufacturing firms. There is recognition that global population growth and urbanization are driving increased demand for industrial durables and capital goods in which Germany has traditionally specialized. Similarly, the German government has recognized that emerging global socio-economic challenges, coupled with breakthrough of new technologies, represent new market opportunities in areas such as health, mobility, and sustainability. As a result, recent policy discussions have highlighted the need for German manufacturers to adapt global strategies to regional and local markets.

New policy approach to effect industrial change

Recent German official publications have argued that the government's role should be limited to ensuring appropriate framework conditions for industrial production by investing in broad areas such as education, energy, and production technologies (BMWi, 2010, 2013a,b). What is more, the German government has recently highlighted that, strictly speaking, industrial policy as a government task has very few instruments of its own at its disposal (BMWi, 2013a). The principles of Ordnungspolitik-pursuing a policy that creates the scope for individuals and companies to act on their own responsibility - have also been referred to in official government publications (see, for example, BMWi, 2013a). Accordingly, the government has declared that rather than attempting to distinguish and favour high-value stages of the chain, it will focus on incorporating 'legitimate interests of industry into relevant policy areas-from education and technology to energy and the environment' (BMWi, 2010, p. 32). 
However, Germany's institutional infrastructure has traditionally allowed the state to combine economy-wide measures with industry-specific institutional support that in turn translates into skills and financial and technological assistance to individual manufacturers (Vitols, 1997; Helper et al., 2012).

In recent years, an increased emphasis on market opportunities abroad is observed in the German industrial policy agenda, particularly those associated with emerging global challenges such as urbanization and increasing demand for resource-efficient technologies. Alongside this new policy agenda, measures have been introduced to $(a)$ boost governmental education and R\&D expenditure; (b) achieve a stronger coordination of policies around a number of 'central missions'; and (c) develop foreign markets.

Three reform initiatives of the federal and the Länder governments feature predominantly as part of the federal government commitment to allocate $€ 12$ billion more than previously planned in the areas of education and research between 2010 and 2013. These knowledge-related measures include: the 'Pact for Research and Innovation' (increased funding to German research organizations by 5 per cent each year between 2011 and 2015), the 'Excellence Initiative' (€2.7 billion increased funding for university-based research between 2011 and 2017, 75 per cent of which was funded by the federal government), and the 'High-Tech Strategy' (the first overarching national innovation strategy adopted in 2006 and expanded in 2010).

Additionally, a number of 'mission-oriented', 'forward-looking' projects have been defined around fields expected to generate 'new jobs and prosperity' and contribute to achieve the 'future viability' of the German economy (BMBF, 2010). These projects will pursue specific objectives related to scientific, technological, and social development over a period of 10-15 years, in the fields of climate/energy (e.g. 'CO2-neutral, energy-efficient, and climate-adapted cities'), health/nutrition (e.g. 'individualized medicine'), mobility (e.g. 'a million electric vehicles in Germany by 2020'), security (e.g. 'more effective protection of communications network'), and communication (e.g. 'ICT Strategy 2020’).

Finally, a number of measures have been established to support the development of new markets by stimulating the acceptance of German products and technologies abroad. Various export promotion measures have been packaged in a single 'programme to develop foreign markets', which includes various export initiatives, as well as a manager training programme. Similarly, GTAI has earmarked additional funds for the network of bilateral chambers of commerce. A number of large-scale bilateral projects have been also financed, including partnerships with Russia to dismantle decommissioned nuclear submarines as well as support to the construction of an urban railway in Vietnam. Other measures include additional support to Germany's participation in world expositions and increased funding to the German National Tourist Board (DZT).

\section{(iv) Japan}

Japan is one the world's most sophisticated manufacturing nations with world-leading firms in a range of industries. Japanese firms specialize in high-quality components and products, and excel in managing complex global industrial networks and sophisticated integration engineering. Japan has a strong cultural association with manufacturing, reflected in the admiration of monozukuri capabilities (Fujimoto, 1999)—roughly speaking, a celebration of high-quality craft and production skills and other value-creating activities associated with the production of goods such as product design and development. According to UNIDO, Japan was responsible for over 14 per cent of the world's manufacturing value added (MVA) in 2010, behind only the US and China.

The proportion of added value produced in Japan's manufacturing industries relative to its nominal GDP has fluctuated around 20 per cent in recent years (Statistics Bureau, 2013). Automotive and electronics represent two major pillars of Japan's manufacturing industries-Japanese firms commanding around 30 per cent global market share in car production and over 60 per cent market share in digital cameras (METI, 2010b). Japanese firms also excel at material processing and 
mechanical production activities, often carried out by smaller firms. They are global leaders in a range of areas such as aircraft components (notably in aerostructure and avionics system components), robots (capturing over 70 per cent of the global market), and fine chemicals (METI, 2010a).

The environment for Japanese manufacturing industries has remained extremely challenging since the global economic crisis of 2008. Just as Japanese manufacturing industries were showing signs of recovery, the country suffered the Great East Japan Earthquake in March 2011, which had long-term harmful effects not only to Japanese but also to global supply chains (Nanto et al., 2011).

Recently, the Japanese government has outlined 'six challenges' that have inhibited growth in the overall economy but that have particularly affected manufacturing industries: a strong yen; higher corporation taxes than competitor nations (Japan's effective corporate rate stands at around 40 per cent); lower wages in emerging economies; environmental restrictions; delayed trade agreements; and electricity supply challenges following the Fukushima Daiichi nuclear disaster (METI, 2011). Moreover, concerns have been raised about Japan's traditional forms of industrial organization, traditionally referred to as keiretsu. Japanese firms have conformed to a 'pyramid structure' of vertical integration whereby smaller firms - producers of components and manufacturing equipment and related industries - are nurtured and protected by larger manufacturers of assembled products to which they supply highly specific components and processes. A build-to-order manufacturing model has been followed, in which SMEs in some industries tend to become dependent on big corporations at the top of the pyramid.

While academic discussions have highlighted both positive and negative effects of the keiretsu structures (Okimoto, 1989), the Japanese government has recently recognized that they have led to domestic wars of attrition and an excessive inward orientation of Japanese firms (METI, 2010b). The result has been lower levels of profitability and investment of Japanese manufacturing firms vis-à-vis international competitors. The government has also associated these industrial structures with the inability of Japanese manufacturing firms, most notably SMEs, to capture business opportunities in growth markets despite Japan's 'dominance' in a range of technologies, leading to a 'win in technology but lose in business’ situation (METI, 2010b).

The government has also recognized that Japan's 'one-legged structure' based on automobiles and electronics poses risks in the future. Notably, there are concerns of 'extreme dependency' on the automotive industry, which was responsible for nearly half of the nominal GDP growth of 2.5 per cent registered in Japan from 2000 to 2007 (METI, 2010b). Meanwhile, there has been a rapid decline of Japanese share in a range of products such as DRAM memory, LC panels, DVD players, solar panels, and car navigation systems (METI, 2010b).

The transfer of production and other high-value-added activities (including research, design, and development) overseas has also raised concerns of an 'irreversible industrial hollowing out', i.e. the permanent loss of key industrial capabilities within Japan (METI, 2011). Over the last few years, R\&D investments by Japanese companies are growing faster abroad than domestically, and some major corporations have decided to relocate key activity outside Japan (e.g. Fujitsu, Nokia, P\&G, and Medtronic relocated or established new operations in Singapore, while Sharp and Novartis did the same in China) (METI, 2010b). In a recent survey of over 11,000 firms, yen appreciation, high labour costs, and problems related to the supply of electricity and other types of energy were the main factors cited as the drivers of the outflow of Japanese industries (METI, 2012). Recent government surveys reveal that offshoring trends are expected to continue and even accelerate in the near future (METI, $2010 b)$.

Another key challenge is the expected shortage of labour due to Japan's ageing population. It is estimated that the country will experience a reduction of $8 \mathrm{~m}$ working-age people by 2020 compared to 2009 (METI, 2010b). As a result, about 10m new workers will be required in the coming 10 years, and an additional $2 \mathrm{~m}$ will be required to change their jobs (METI, 2012). 
New policy approach to effect industrial change

The Japanese state assumed a developmental role in the post-war period to the 1980s, marked by a leading role of the Ministry of International Trade and Industry, MITI (Johnson, 1982). As the Japanese economy stopped growing, reforms in the 1990s onwards started to redefine the role of MITI and the Japanese state in the affairs of industry. As the result of an overall transformation of government ministries in 2000, MITI was reorganized into the Ministry of Economy, Trade and Industry, or METI - a change that has meant an increased emphasis on cross-cutting policies over sector-specific approaches (Nezu, 2007).

Despite these institutional changes, manufacturing industries have consistently received special attention in Japanese policy-making over the last few years. Recently, however, there has been a growing recognition of the need for a more active role of the state in strengthening industrial competitiveness in the face of mounting challenges faced by Japanese firms (METI, 2010b). A new policy agenda has emerged, which seeks to facilitate a reorganization of the domestic industrial structure and promote a more active participation of Japanese firms in global markets. The intention is to support a shift from a 'mono-pole' structure based on automotive and electronics, towards a sustainable 'multi-pole' one, enabled by the development of five 'strategic industrial fields': infrastructure-related industries (e.g. nuclear, water, and railroad); next-generation energy solutions (e.g. smart communities and next-generation automobiles); creative industries; health-related industries; and frontier fields (e.g. robots and space).

This new policy agenda has driven the establishment of a range of measures to (a) improve Japan's overall attractiveness as a manufacturing hub, $(b)$ support the deployment of Japan's technologies and products into the world market, and $(c)$ address energy supply shortages.

To improve Japan's overall competitiveness as a manufacturing hub, measures have included: a tax reform that seeks to take Japan's corporate taxes closer to international levels; new incentives to attract high-added-value corporate functions to Japan (with emphasis on Asian headquarters and R\&D bases); and increased investment in logistics infrastructure. New long-term funds have also been made available to support business restructuring, with emphasis on supporting start-ups and firms' diversification efforts. Recent measures to improve the 'quality and quantity' of the Japanese labour force include: the creation of national vocational qualifications modelled on the UK's system; the promotion of 'second life' career opportunities for older workers; training programmes designed to transmit the skills of experienced workers to younger generations; as well as new measures to increase female employment and attract high-level human resources from abroad.

In order to support the deployment of Japan's technologies and products into the world market, the government has promoted the move from the sale of individual products with advanced functions to the provision of integral solutions combining manufacturing and service components (i.e. from the sale of stand-alone products to the deployment of systems) in areas where Japan is perceived to have a competitive edge, i.e. to 'win by technology and by business'. Emphasis has been placed on the deployment of low-carbon energy generation and distribution technologies in high-growth, mainly Asian economies. Specific measures related to this strategy include: demonstration projects in developing countries, an international standardization strategy, as well as the promotion of investment agreements and exports through top-level diplomacy and the work of the Japanese International Cooperation Agency (JICA).

A number of measures have also been put into place to address the perceived inward-looking tendency of the traditional 'pyramid' structures of Japanese industries and encourage SMEs to compete in global markets. Examples include: the creation of an SMEs' overseas expansion support programme, extended guaranty insurances on overseas expansion, as well as new technical advisory services.

New cutting-edge 'world-class R\&D centres', with the participation of industry, academia, and government, have also been announced to promote industrial agglomeration and the 
commercialization of joint research. These centres are expected to contribute to further R\&D investment in the private sector and contribute to achieving the national R\&D investment goal of 4 per cent of GDP by 2020.

Finally, a number of measures have been introduced following the Great East Japan Earthquake of March 2011. Since Japan depends on imports to satisfy more than 90 per cent of its energy demand, a guiding objective has been ensuring a stable energy supply from overseas. Bilateral collaborative frameworks with resource-rich nations have been expanded-typically involving infrastructure development projects with the participation of Japanese firms - and the supply of risk money for resource exploitation and development projects has been enhanced. The Japan Bank for International Cooperation (JBIC) was restructured in 2012, taking over some functions of the Japanese Finance Corporation (JFC). One of its central aims is to conduct financial operations leading to the 'overseas development and securement of resources which are important for Japan' (JBIC, 2012, p.6). New surveys and R\&D projects have also been funded for developing domestic resources, and a new raremetals recycling programme has been established.

\section{Changes in industrial policies across selected countries: a comparison}

This section compares and contrasts some of the recent changes in manufacturingrelated policies of national governments (see Figure 2 and Table 1).

In particular, we compare:

- countries' different policy agendas and their intended changes;

- some of the most striking variations in policy measures designed to effect change in national factors of production;

- the degree to which these measures focus on particular industrial sectors, specific cross-sector manufacturing activities, or broader economic conditions-i.e. levels of policy intervention;

- $\quad$ the extent to which the new measures are coordinated within coherent strategies.

We attempt to account for variations in the division of responsibility for priority-setting and policy implementation between national governments, regional governments, self-governing industrial networks, and regional economic institutions.

\section{(i) Policy agendas and key intended changes}

Policy agendas in both US and UK reflect the perceived need to reverse de-industrialization. The US is focusing on three traditional clusters of policy measures - competitiveness conditions, export promotion, and manufacturing $\mathrm{R} \& \mathrm{D}$ - while the UK focuses on rebalancing the economy by supporting long-term growth in key industrial sectors.

Germany and Japan - widely regarded as leading manufacturing nations - emphasize the need to participate in markets and industries expected to drive future growth. In Japan, the government has sought to actively promote the reorganization of the domestic industrial structure, particularly to address the inward-looking orientation of SMEs. In Germany, where SMEs have traditionally been able to participate in global markets, the emphasis has been on increasing $R \& D$ expenditure and coordinating policy efforts around socio-economic challenge-driven future market.

\section{(ii) Policy measures across factor inputs}

\section{Knowledge}

One of the most striking emerging themes across different national manufacturing-related strategies is the importance of manufacturing-related R\&D (including research addressing the manufacturability challenges of emerging technologies). This increased attention is reflected in, for example, the US, where there have been a number of high-profile analyses of 'advanced manufacturing' and manufacturing-related innovation, and in the UK, where the government is currently carrying out a major manufacturing-focused foresight exercise. 
In the US and the UK, this new attention to manufacturing-related R\&D and the industrialization of emerging technologies has resulted in the creation of new R\&D organizations-the UK 'Catapult' technology and innovation centres and the US National Manufacturing Innovation Institutes- to varying degrees modelled on German Fraunhofer Institutes. These new R\&D organizations not only provide support for later stage, product-focused, technology R\&D, but also manufacturing-related innovation in areas such as production technologies and supply chain development.

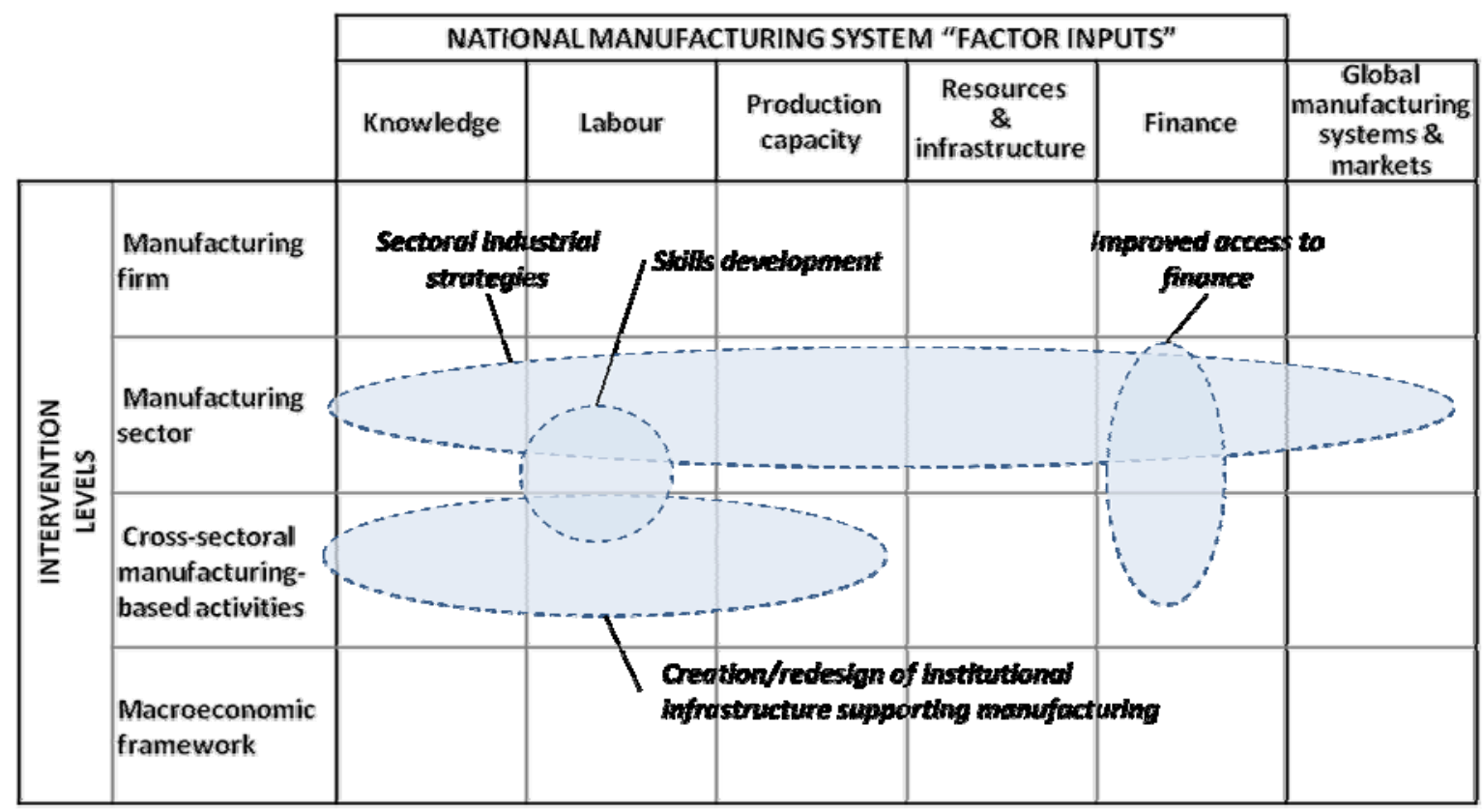

US

Policy Agenda: Reversing manufacturing decline and re-shoring productive capacity

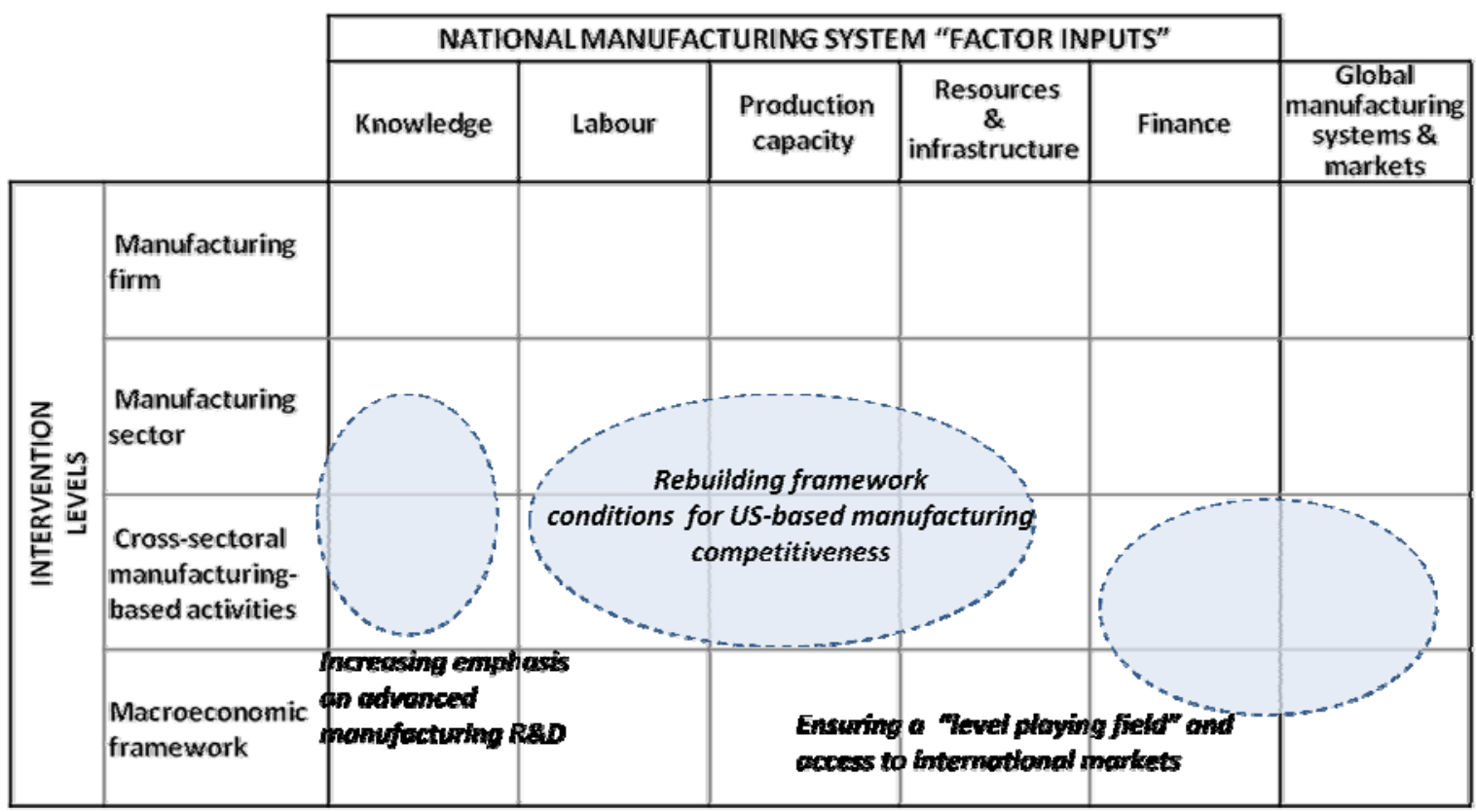


GERMANY Policy Agenda: Increased policy coordination and focus on growth industries associated to emerging global socio-economic challenges

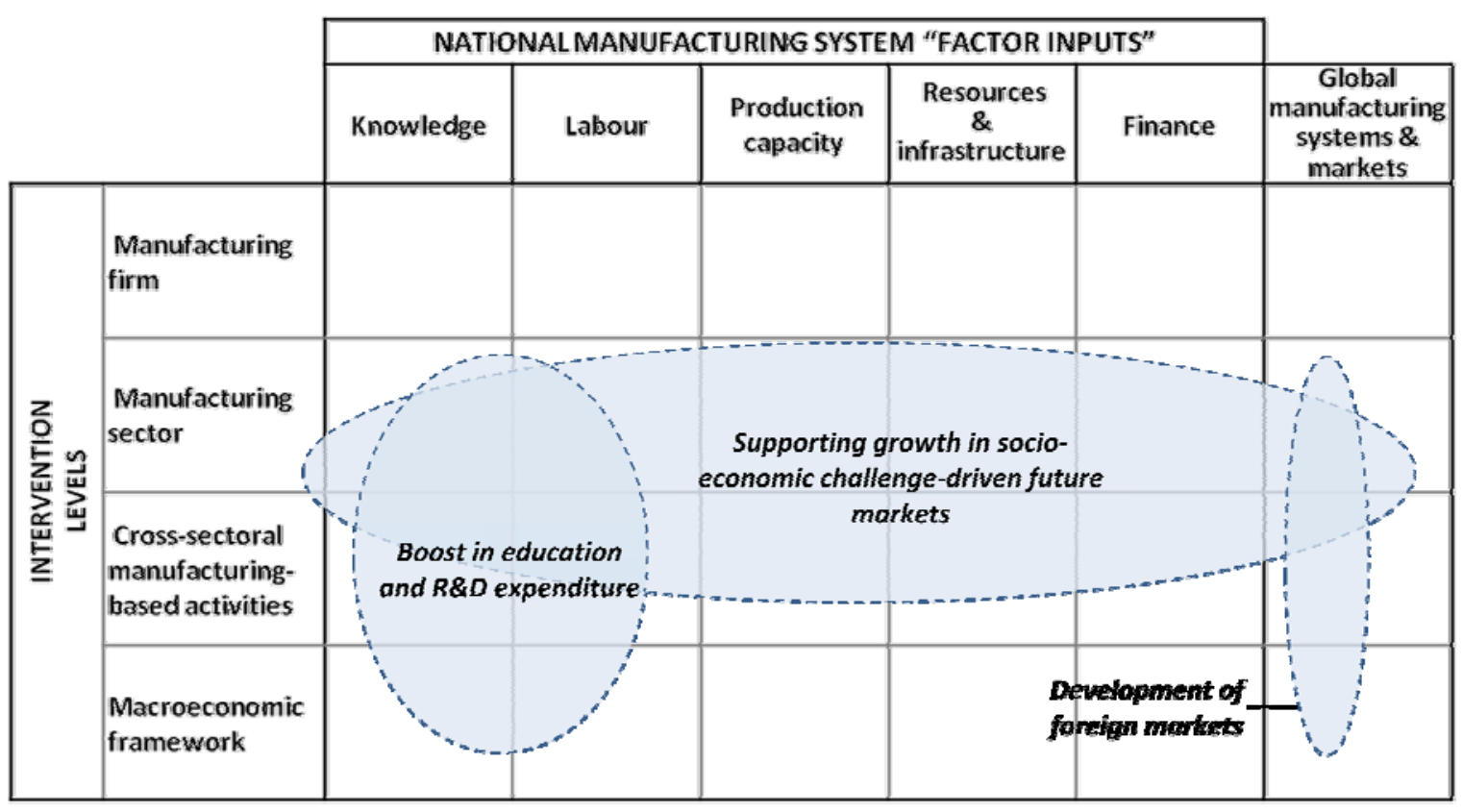

JAPAN

Policy Agenda: Reorganisation of the domestic industrial structure and increased participation in global markets

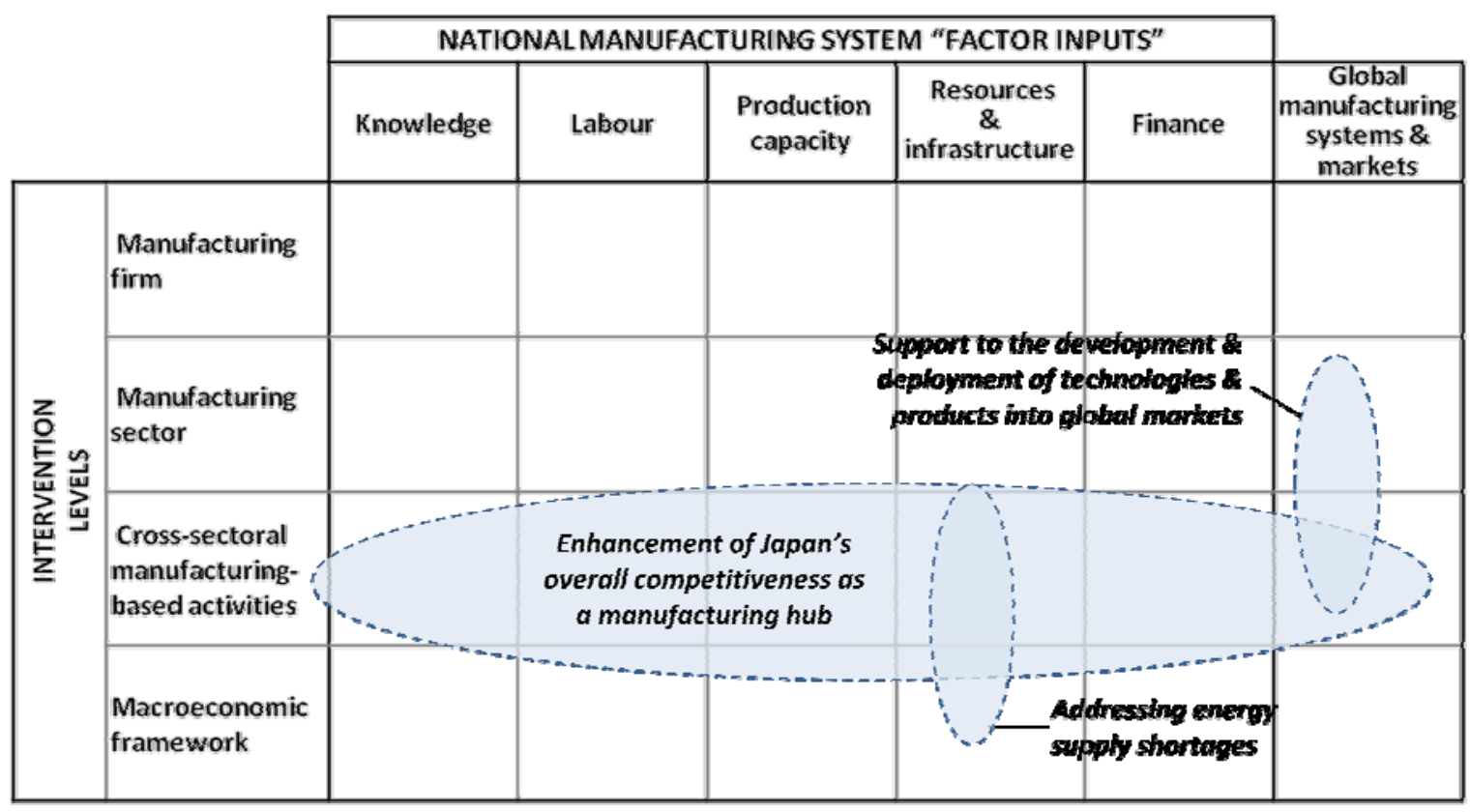

Figure 2: Comparison of policy approaches across the policy matrix

Note: For each country's policy agenda, circles represent clusters of policy measures supporting key intended changes. Some exemplary policy measures, grouped according to the intended policy changes, are listed in Table 1. 
Table 1: Comparison of policy agendas, key intended changes and policy measures

\begin{tabular}{|c|c|c|c|}
\hline Country & Policy Agenda & Key Intended Changes & Example Policy Measures $^{\text {a }}$ \\
\hline \multirow[t]{4}{*}{ UK } & \multirow[t]{4}{*}{$\begin{array}{l}\text { "Rebalancing" the economy and } \\
\text { supporting growth in key } \\
\text { manufacturing sectors }\end{array}$} & $\begin{array}{l}\text { Creation/redesign of institutional infrastructure } \\
\text { supporting manufacturing }\end{array}$ & $\begin{array}{ll} & \text { Catapult Centres } \\
- & \text { Manufacturing Advisory Services (MAS) } \\
- & \text { Small Business Research Initiative (SBRI) }\end{array}$ \\
\hline & & Supporting long-term growth in key industrial sectors & $\begin{array}{ll} & \text { National Aerospace Strategy } \\
\text { - } & \text { Strategy for UK Life Science } \\
\text { - } \quad & \text { Nuclear Industrial Strategy } \\
\text { - } & \text { UK Oil and Gas: Business and Government Action Plan }\end{array}$ \\
\hline & & Access to "patient” financial capital & $\begin{array}{ll} & \text { Business Bank } \\
- & \text { Funding for Lending Scheme } \\
\text { - } \quad \text { Enterprise Capital Funds } \\
\text { - } & \text { Business Finance Partnership } \\
\end{array}$ \\
\hline & & Skills development & - $\quad$ Employment Ownership Pilot \\
\hline \multirow[t]{3}{*}{ US } & \multirow[t]{3}{*}{$\begin{array}{l}\text { Reversing manufacturing decline and } \\
\text { re-shoring productive capacity }\end{array}$} & $\begin{array}{l}\text { Rebuilding framework conditions for US-based } \\
\text { manufacturing competitiveness }\end{array}$ & $\begin{array}{ll} & \text { Clean Energy Initiative (ARRA) } \\
- & \text { Manufacturing Extension Partnerships } \\
- & \text { Advanced Energy Manufacturing R\&D Tax Credit } \\
- & \text { Insourcing income tax credit } \\
\text { - } & \text { STEM Initiative (Innovate American Act) }\end{array}$ \\
\hline & & $\begin{array}{l}\text { Ensuring a "level playing field" and access to } \\
\text { international markets }\end{array}$ & $\begin{array}{ll} & \text { National Export Initiative } \\
-\quad & \text { Export-Import Bank } \\
\text { - } & \text { Interagency Trade Enforcement Centre } \\
\end{array}$ \\
\hline & & Increasing emphasis on advanced manufacturing R\&D & $\begin{array}{ll} & \text { National Network of Manufacturing Innovation } \\
\text { - } & \text { Materials Genome Initiative } \\
\text { - } \quad \text { Sobotics Initiative } \\
\end{array}$ \\
\hline \multirow[t]{3}{*}{ Germany } & \multirow{3}{*}{$\begin{array}{l}\text { Increased policy coordination and } \\
\text { focus on growth industries associated } \\
\text { to emerging global socio-economic } \\
\text { challenges }\end{array}$} & Boost in education and $\mathrm{R} \& \mathrm{D}$ expenditure & $\begin{array}{ll} & \text { Pact for Research and Innovation } \\
\text { - } & \text { Excellence Initiative } \\
\text { High-Tech Strategy }\end{array}$ \\
\hline & & $\begin{array}{l}\text { Supporting growth in socio-economic challenge-driven } \\
\text { future markets }\end{array}$ & $\begin{array}{l}\text { - } \quad \text { ICT Strategy } 2020 \\
\text { - } \quad \text { CO2-Neutral, Energy Efficient and Climate Adapted Cities } \\
\text { - }\end{array}$ \\
\hline & & Foreign markets development & $\begin{array}{ll}\text { - } & \text { Programme to develop foreign markets } \\
\text { - } & \text { Additional funds for the network of bilateral chambers of commerce } \\
\text { - } \quad \text { Large-scale bilateral projects } \\
\end{array}$ \\
\hline \multirow[t]{3}{*}{ Japan } & \multirow[t]{3}{*}{$\begin{array}{l}\text { Reorganisation of the domestic } \\
\text { industrial structure and increased } \\
\text { participation in global markets }\end{array}$} & $\begin{array}{l}\text { Enhancement of Japan's overall competitiveness as a } \\
\text { manufacturing hub }\end{array}$ & $\begin{array}{ll} & \text { Corporate tax reform } \\
\text { - } & \text { New incentives to attract key corporate functions } \\
\text { - } & \text { Increased investment in logistics infrastructure } \\
\text { - } & \text { New long-term funds for business restructuring } \\
\end{array}$ \\
\hline & & $\begin{array}{l}\text { Development and deployment of Japanese technologies } \\
\text { and products into global markets }\end{array}$ & $\begin{array}{ll} & \text { Demonstration projects in developing countries } \\
\text { - } \quad \text { International standardisation strategy } \\
\text { - } \quad \text { Creation of a SMEs' overseas expansion support programme } \\
\end{array}$ \\
\hline & & Addressing energy and natural resource supply shortages & $\begin{array}{ll}\text { - } & \text { Expansion of collaborative frameworks with resource-rich nations } \\
\text { - } & \text { Reorganisation of the Japan Bank for International Cooperation (JBIC) } \\
& \text { Rare metals recycling programme }\end{array}$ \\
\hline
\end{tabular}

Note: ${ }^{a}$ Includes new measures as well existing measures that have received significantly new funding or have been significantly redesigned. New measures in italics. 
By contrast, in Germany, although there has been a marked increase in R\&D funding, changes in key organizations and funding routes have been less dramatic.

Although the importance of SME-based manufacturing research and innovation is highlighted in many national studies, this can be implemented quite differently. In Germany, not only is significant SME-relevant R\&D supported by Fraunhofer Institutes, but the German government supports the Federation of Industrial Research

Associations (the AiF) programmes for application-oriented R\&D at SMEs. In the UK and US, there is greater interest in R\&D 'procurement' via small business innovation research grants managed by R\&D agencies (e.g. Small Business Innovation Research (SBIR) and Small Business Research Initiative (SBRI)). In Japan, new 'world class R\&D centres', bringing together industry, academia, and government, have been established to support industrial agglomeration in selected regions and industry sectors such as automotive and aerospace.

\section{Production capacity}

All the countries have a range of national manufacturing support programmes helping SMEs with production technology adoption and process improvement, sustainable manufacturing, export assistance, etc. These programmes are provided by a range of different organization types. For example, as part of the broader offerings of established industry technology research centres in Japan (Kosetsushi Centres) and Germany (Fraunhofer Institutes and Steinbeis Centres); but more focused business advisory services in the UK (Manufacturing Advisory Service) and US (Manufacturing Extension Partnership). Across all the countries, there appears to be an evolution in the emphasis on different types of support activities over the last decade or so, from a focus on lean manufacturing approaches or quality issues to increasing attention paid to product $R \& D$, manufacturing innovation, and engaging in global markets (including navigating international standards or regulatory requirements).

\section{Labour}

All of the manufacturing policy-related strategies highlighted challenges related to the availability of engineering skills, both in terms of quantity (often contrasted with the number of engineers being produced in China and other emerging manufacturing economies) but also quality-particularly the ability to adopt emerging production technologies and manufacturing management practices. In Japan and Germany, changing demographics associated with an ageing manufacturing engineering population are causing increasing concern.

It is worth noting that in Germany, Japan and the United States many important manufacturing skills initiatives are funded by regional governments. In the UK, skills are a central part of the new industrial sector strategies. Furthermore, the range and scope of supporting institutions involved in manufacturing skills development can vary significantly from country to country. Many regional intermediate R\&D institutes also play an important role in producing a skilled workforce with experience or awareness of the latest production technologies or manufacturing management methods, thus responding to the particular needs of regional industrial clusters.

An important focus of recent UK skills policy has been on apprenticeships, but even in countries with more established and prominent vocational systems, notably Germany's two-tier system, there have been increases in funding in this area. By contrast with the UK, where work-based training is the responsibility of the private sector, in Germany, practical vocational training takes place in firms (part supported by the federal government), while additional complementary educational training takes place in local vocational schools (part supported by the Länder). The standards and rules for vocational training are typically set by Chambers of Commerce (or other self-governing economic or industrial networks).

\section{Resources and infrastructure}

The challenges of sustainable, resource-efficient manufacturing are an important theme within the industrial policies of all the countries considered in this paper. There are, however, important nation- 
specific drivers of policy interest in energy and natural resource- different contexts with consequences for national policy emphases and actions. In Japan, manufacturing-related energy challenges are not only exacerbated by a lack of natural resources and energy price volatility, but the Fukushima nuclear power station disaster has resulted in major new energy-supply-related policy initiatives. By contrast, in the US pressure for policy action on energy supply and pricing for manufacturing has been alleviated by a drop in energy prices as a result of advances in horizontal drilling and hydraulic fracturing ('fracking') to obtain natural gas and petroleum.

The opportunities offered by new 'green technology' manufacturing industries are a common feature, perhaps most notably in Germany, where traditional strengths in production technologies and precision engineering are considered a strong platform for taking advantage of new global markets for a range of 'industrial environmental and climate protection goods'. Government support for the emerging electric vehicles sector provides an interesting example of evolving international manufacturing policies.

In 2003, the UK government used its convening capabilities to support a public-private partnership (the 'Low Carbon Vehicles Partnership', LowCVP) which brought together a diverse range of stakeholders from the automotive sector and fuel supply chains, vehicle users, academic researchers, as well as environment groups. In 2009, perhaps reflecting increasing comfort with the concept of industrial strategy, the emerging low carbon-vehicles sector was a central pillar of a broader 'UK Low Carbon Industrial Strategy'. By 2012, the exploitation of low-carbon technologies was a declared aim of the UK government's planned automotive sector strategy. The German and US governments have set out clear goals for the electric vehicle sector, with declared policy visions of one million electric cars being on the road in each nation (by 2020 and 2015, respectively), albeit goals that are increasingly looking over-ambitious. Despite the ambitious vision, direct German government support for electric vehicles is largely limited to R\&D investment,. Electric vehicle-related technologies are an important research priority in all the countries, with particular attention to battery technology research (and associated manufacturing R\&D).

\section{Financial capital}

Access to finance for manufacturing-based firms is an important theme across all the industrial policy documents reviewed in this study. Although many of the other factor input policies discussed elsewhere in this paper have been motivated by a variety of drivers, the impact of the recent financial crisis can be most clearly seen in measures to address access to financial capital, especially for SMEs. The nature and supply of finance for investment in manufacturing firms in different countries was affected differently by the crisis. In Germany, for example, the many family-owned manufacturing firms continued with longer-term investment strategies facilitated by high equity rates and regional and federal government-owned banks. The UK government has put in place a range of measures to help firms access bank finance, perhaps most strikingly the allocation of $£ 1$ billion of new government funding to a new 'Business Bank' to increase levels of private-sector investment in firms. By contrast, Germany has a well-established business bank, KfW, focused on SMEs, and with activities and subsidiaries addressing a range of factor-input-related activities (e.g. export finance, education and training loans, energy and resource efficiency). In Japan, reflecting the focus on international engagement and export opportunities, the government-owned business banks, the Japan Finance Corporation and the Japanese Bank for International Cooperation, provide long-term financing for foreign investments and international commerce, particularly to SMEs. Similarly, in the US, there is an established Export/Import Bank, supporting manufacturing-based firms, including particular mechanisms to support SMEs, which have experienced a massive increase in available financing since the financial crisis.

\section{Global manufacturing systems and markets}

Attention to manufacturing exports, engagement with emerging global markets, and integration within international manufacturing systems are common themes. However the emphases and priorities, as well as measures deployed and institutions involved, vary from country to country. In Japan there is significant focus on how manufacturing SMEs, which have traditionally lived within 'pyramid' value 
chains, can integrate more effectively with global value chains, taking advantage of their technology and engineering strengths to gain greater market share for their goods or services across a greater range of sectors. In the US, the recent 'National Export Initiative' focuses not only on export assistance and financing for SMEs, but also on improving market access for US firms, by opening new markets and enforcing trade agreements.

In addition to policy attention on export markets, the US policy debate has a particular emphasis on the 'reshoring' of manufacturing activities by US firms, which has resulted in measures such as the reversal of tax incentives to encourage relocation of manufacturing jobs back to the United States. In the UK, there is significant emphasis on inward investment, including the formation of new organizations such as the Automotive Investment Organization which will be led by UK Trade \& Invest with support from the Automotive Council. By contrast, other countries have different organizations supporting export or FDI efforts, for example, the activities of German Trade \& Invest are complemented by the activities of the German Chambers of Commerce.

\section{(iii) Levels of policy intervention}

Firm level

Across the countries considered in this study, one of the most striking observations is the lack of initiatives at the firm level. In other words, no efforts to 'pick winners' or nurture 'national champions' were observed. However, individual firms were in some cases named in the context of 'partnerships' between the public and private sectors. For example, the UK's Aerospace Industrial Strategy was developed in collaboration with a number of selected industry partners.

\section{Sector level}

The focus on particular industrial sectors is a common feature of many manufacturing strategies. In the UK, a number of long-term 'strategic partnerships' with selected industry sectors have been established and national sectoral strategies have been announced. By contrast, the German government has declared that it favours a sector-neutral approach, though support is provided to sector-level industry associations. Although most of the measures announced in Japan are largely horizontal, sector-specific support is provided in 'strategic fields'. Indeed, the functions of METI are structured around industry sectors.

\section{Cross-sector manufacturing}

There were many similarities in policy interventions with impact across multiple sectors (and along various supply chains) of national manufacturing systems. In the US, the emphasis on cross-sectoral manufacturing activities is reflected in recent programmes on 'advanced manufacturing' which support cross-sectoral general-purpose technologies. Similarly, Germany has traditionally supported cross-sectoral R\&D, and the UK has more recently established such programmes and organizations to that effect. In Japan, R\&D in cross-sectoral 'supporting industries', such as materials process technology, mechatronics, and robot technology, is being supported.

\section{Macroeconomic framework}

Initiatives can be found in all the countries studied. Japan has sought to improve national competitiveness by introducing tax reform, relaxing immigration laws, and by establishing initiatives to address labour shortages. Germany is supporting basic science R\&D to ensure the supply of ideas and has established bilateral chambers of commerce to promote exports, while the US government has placed emphasis on enforcing trade agreements and ensuring access to international markets.

\section{(iv) Degree of policy coordination}

There are differences in the degree of coordination of measures - the extent to which they are part of a coherent strategy by national governments to nurture particular industrial activities or particular features of national manufacturing systems. 
In the UK, the most striking development in approaches to manufacturing-related industrial policy is sector-focused and involves measures across the range of factor inputs. In particular, the government has adopted sector-based 'industrial strategies' which, in partnership with industry organizations, develop longer-term coherent plans to address skills needs, technology, R\&D, access to finance, and procurement. By contrast, the German government continues to avoid federal-led sector policies. Despite this, however, German public support for sector-specific factor inputs does achieve a high level of coordination and coherence through the role in priority-setting and policy implementation played by a range of self-governing industrial network organizations or economic institutions.

In Japan, perhaps the most significant shift in the industrial policy role of government is the focus on measures to catalyse changes to industrial structures - in particular, initiatives that support manufacturing SMEs, which have traditionally lived within 'pyramid' value chains topped by major firms (dominated by automotive and ICT) to integrate more effectively with global value chains, gaining greater market share for products or services across a greater range of sectors. In contrast to these more 'horizontal' Japanese initiatives, US manufacturing policy efforts focus on knowledgerelated factor inputs - production-related $\mathrm{R} \& \mathrm{D}$, the manufacturing challenges of emerging technologies, and the organizational forms and networks to deliver them.

\section{Conclusions}

Following the financial crisis, national debates about the potential merits of 'industrial policy' (and the importance and future of manufacturing) appear to have intensified as national governments looked more urgently for new ways to support growth and employment. Growing concerns about the decline of manufacturing, climate change and resource efficiency, and, in particular, globalization, have stimulated renewed interest and debate about the appropriate role of government in supporting specific sectors, technologies, or areas of industrial activity over the last decade and more.

Although a set of (largely) common 'megatrends' are driving 'industrial policy', new policy initiatives in different countries are contingent on: the particular national industrial context (sector structures, value chain configurations, etc.); the national policy context (the missions and functions of different ministries, agencies, etc.); and institutional context (the roles played by other national stakeholder organizations, e.g. regional governments, industrial networks, chambers of commerce). So, although new policy approaches and emphases in the different countries are responding to similar trends, the nature of the policy measures (analysed here using the 'policy matrix') appears to be significantly different among countries included in the analysis. It is difficult to make the case based on the evidence gathered in this study, that there is any general convergence on a particular 'new' approach to 'industrial policy'.

Nevertheless, there is some evidence of a convergence on the adoption of particular programmes and organizational types. For example, the stated UK policy rationales for initiatives cite international models. To give some examples: the policy rationales for the Catapult programme reference the German Fraunhofer model; the UK SBRI programme references the established US SBIR initiative; and the case for the UK 'Business Bank' references the German government bank, KfW.

Furthermore, there also appear to be some common themes increasingly reflected across national industrial policy debates and strategies. In particular, we found evidence of an increasing consensus on certain 'qualities' a national manufacturing system should have to maintain its competitiveness, with important implications for the potential role of government. In particular, we observed increasing emphasis on:

- coordination and alignment of manufacturing-related policy measures and the convening power of government to enhance alignment and awareness among industry actors;

- 'partnership' with industry in designing manufacturing-support programmes, in particular, in terms of ensuring information gathering on the competitiveness challenges facing firms, not least in the context of complex global value chains;

- longer-term investment and planning in the context of programme design, policy continuity, and investment prioritization; in particular, to ensure that government efforts to nurture an 
environment conducive to manufacturing-related investment are commensurate with planning of activities of manufacturing firms themselves.

More generally, the comparison of policy matrices reveals that countries are paying increasing attention to the systems-nature of manufacturing and the challenges to policymaking posed by the increasingly complex interdependencies across a range of industries. Not only are many of the most promising emerging technologies likely to be embodied in complex application systems, but their manufacture relies on complex supply networks contributing components, materials, production systems and subsystems, producer services, and product-related service systems. In this context, we argue that any industrial policies which endeavour to take a longer-term and more selective systemsbased view of key manufacturing sectors may need to be underpinned by more careful analysis of the dynamics and national-value-capture opportunities of manufacturing systems.

This 'policy matrix' approach to analysing national policy measures proved effective in revealing distinct differences in terms of new policy measures or approaches being explored in each country, and the government agencies and (non-governmental) stakeholder institutions charged with delivering them. We believe that our policy matrix approach may help to provide new insights into the mechanisms, targeting, and potential impact of policies. In due course it may help the evaluation and design of policies at local, national, and international levels.

\section{References}

- $\quad$ Abele, E., and Reinhart, G. (2011), Zukunft der Produktion: Herausforderungen, Forschungsfelder [The Future of Production: Challenges, Research Areas, Opportunities], Hanser Fachbuchverlag.

- $\quad$ Amsden, A. H. (1989), Asia’s Next Giant: South Korea and Late Industrialization, New York, Oxford University Press.

- $\quad$ Andreoni, A. (2013), 'Structural Learning: Embedding Discoveries and the Dynamics of Production', Structural Change and Economic Dynamics, forthcoming.

- $\quad$ Andreoni, A., and Scazzieri, R. (2013), 'Triggers of Change: Structural Trajectories and Production Dynamics', Cambridge Journal of Economics, forthcoming.

- $\quad$ Bianchi, P., and Labory, S. (2011), Industrial Policy After the Crisis: Seizing the Future. Cheltenham, UK, and Northampton, MA, USA, Edward Elgar.

- $\quad$ BIS (2012a), Industrial Strategy: UK Sectoral Analysis, London, Department for Business, Innovation and Skills.

- $\quad$ BIS (2012b), Strengthening UK Supply Chains: Public Procurement, London, Department for Business, Innovation and Skills.

- $\quad$ BIS (2013), Building the Business Bank. Strategy Update, London, Department for Business, Innovation and Skills.

- $\quad$ BMBF (2010), High Tech Strategy 2020 for Germany. Federal Ministry of Education and Research (BMBF).

- $\quad$ BMWi (2010), Germany as a Competitive Industrial Nation, Federal Ministry of Economics and Technology.

- $\quad$ BMWi (2012), German Mittelstand: Engine of the German economy. Facts and figures about small and medium-sized German firms. Federal Ministry of Economics and Technology. retrieved May 2013 from http://www.BMWi.de/English/Redaktion/Pdf/factbook-german-mittelstand.pdf

- BMWi (2013a), 2013 Annual Economic Report, Federal Ministry of Economics and Technology.

- $\quad$ BMWi (2013b), Industrial Policy, retrieved April 2013 from http://www.bmwi.de/EN/Topics/Economy/industrial-policy,did=76808.html

- $\quad$ Cable, V. (2012), Letter to the Prime Minister, London, Department for Business, Innovation and Skills.

- Cattaneo, O., Gereffi, G., and Staritz, C. (2010), Global Value Chains in a Postcrisis World: A Development Perspective, Washington, DC, World Bank Publications. 
- $\quad$ Chaminade, C., and Edquist, C. (2006), 'Rationales for Public Policy Intervention from a Systems of Innovation Approach: The Case of VINNOVA’, CIRCLE Working Paper 2006/04, Lund University.

- Chang, H.-J. (2002), Kicking Away the Ladder: Development Strategy in Historical Perspective, London, Anthem Press.

- Chang, H.-J. (2011), 'Industrial Policy: Can We Go Beyond an Unproductive Confrontation?’, in J. Y. Lin and B. Pleskovic (eds), Annual World Bank Conference on Development Economics 2010, Global: Lessons from East Asia and the Global Financial Crisis, Washington, DC, World Bank, 83-109.

- $\quad$ Chang, H.-J., Andreoni, A., and Kuan, M. L. (2013), 'International Industrial Policy Experiences and the Lessons for the UK', policy report for the UK Foresight Future of Manufacturing Project, UK Government Office of Science.

- $\quad$ Cimoli, M., Dosi, G., and Stiglitz, J. E. (eds), (2009), Industrial Policy and Development: The Political Economy of Capabilities Accumulation, New York, Oxford University Press.

- $\quad$ Coe, N. M., Dicken, P., and Hess, M. (2008), 'Global Production Networks: Realizing the Potential', Journal of Economic Geography, 8(3), 271-95.

- $\quad$ Di Tommaso, M., and Schweitzer, S. (2013), Industrial Policy in America, Cheltenham and Northampton, MA, Edward Elgar.

- $\quad$ Dodgson, M., Hughes, A., Foster, J., and Metcalfe, S. (2011), 'System Thinking, Market Failure, and the Development of Innovation Policy: The Case of Australia', Research Policy, 40, 1145-56.

- Domestic Policy Council (2006), American Competitiveness Initiative, Washington, DC, Domestic Policy Council.

- $\quad$ Dore, R. P. (1986), Flexible Rigidities: Industrial Policy and Structural Adjustment in the Japanese Economy, 1970-80, Stanford, CA, Stanford University Press.

- $\quad$ Edquist, C. (ed.) (1997), Systems of Innovation: Technologies, Institutions and Organisation, London, Cassel.

- $\quad$ EOP (2012), A National Strategic Plan for Advanced Manufacturing, Washington, DC, Executive Office of the President of the US.

- $\quad$ PCAST (2011), Report to the President on Ensuring American Leadership in Advanced Manufacturing, Washington, DC, Executive Office of the President of the US and President's Council of Advisors on Science and Technology.

- $\quad$ Evans, P. (1995), Embedded Autonomy, Princeton, NJ, Princeton University Press.

- $\quad$ Ezell, S. J., and Atkinson, R. D. (2011), International Benchmarking of Countries’ Policies and Programs Supporting SME Manufacturers, Washington, DC, Information Technology and Innovation Foundation.

- $\quad$ Freeman, C. (1987), Technology Policy and Economic Performance: Lessons from Japan, London, Pinter.

- $\quad$ Fuchs, E. (2010), 'Rethinking the Role of the State in Technology Development: DARPA and the Case For Embedded Network Governance', Research Policy, 39, 1133-47

- Kirchain, R. (2010), 'Design for Location? The Impact of Manufacturing Offshore on Technology Competitiveness in the Optoelectronics Industry’, Management Science, 56(12), 2323-49.

- $\quad$ Fujimoto, T. (1999), The Evolution of a Manufacturing System at Toyota, New York, Tokyo, Oxford University Press.

- $\quad$ Gereffi, G., Humphrey, J., and Sturgeon, T. (2005), 'The Governance of Global Value Chains', Review of International Political Economy, 12(1), 78-104.

- $\quad$ GTI (2011), The Photovoltaic Industry in Germany, Berlin, Germany Trade and Invest, retrieved May 2013 from http://www.gtai.de/GTAI/Content/CN/Invest/_SharedDocs/Downloads/GTAI/Industryoverviews/industry-overview-photovoltaics.pdf

- $\quad$ GTI (2013), Germany’s Wind Energy Industry, Berlin, Germany Trade and Invest, retrieved May 2013 from http://www.gtai.de/GTAI/Content/EN/Invest/_SharedDocs/Downloads/GTAI/Fact-sheets/Energyenvironmental/fact-sheet-wind-energy-in-germany.pdf

- Hall, P. (1986), Governing the Economy: The Politics of State Intervention in Britain and France, New York, Oxford University Press. 
- $\quad$ Helper, S., Krueger, T., and Wial, H. (2012), Why Does Manufacturing Matter? Which Manufacturing Matters? A Policy Framework, Advanced Industries Series Paper, The Brookings Institution.

- HM Government (2009) Building Britain’s Future: New Industry, New Jobs, London, HM Government.

- $\quad$ HM Government (2013), Lifting Off-Implementing the Strategic Vision for UK Aerospace, London.

- JBIC (2012), 2012 Annual Report. Japan Bank for International Cooperation.

- Johnson, C. (1982), MITI and the Japanese Miracle: The Growth of Industrial Policy, 1925-1975, Stanford, CA, Stanford University Press.

- Jovane, F., Westkämper, E., and Williams, D. (2009), The ManuFuture Road: Towards Competitive and Sustainable High-Value-Adding Manufacturing, Springer Verlag.

- Ketels, C. H. (2007), 'Industrial Policy in the United States', Journal of Industry, Competition and Trade, 7(3/4), 147-67.

- $\quad$ Klein Woolthuis, R., Lankhuizen, M., and Gilsing, V. (2005), ‘A System Failure Framework for Innovation Policy Design', Technovation, 25, 609-19.

- $\quad$ Kuznetsov, Y., and Sabel, C. (2011), 'New Open Economy Industrial Policy: Making Choices without Picking Winners', World Bank PREMNotes N. 161.

- $\quad$ Lin, J. Y. (2012), New Structural Economics: A Framework for Rethinking Development and Policy, Washington, DC, World Bank.

- $\quad$ López-Gómez, C., O’Sullivan, E., Gregory, M., Fleury, A., and Gomes, L. (2013), Emerging Trends in Global Manufacturing Industries and Implications for Latin America, report prepared for the United Nations Industrial Development Organisation.

- $\quad$ Lundvall, B. A. (ed.) (1992), National Systems of Innovation: Towards a Theory of Innovation and Interactive Learning, London, Pinter.

- $\quad$ Malerba, F. (2002), 'Sectoral System of Innovation and Production’, Research Policy, 31, 247-64.

- $\quad$ Metcalfe, S. (1995), 'Technology Systems and Technology Policy in an Evolutionary Framework', Cambridge Journal of Economics, 19, 25-46.

- $\quad$ METI (2010a), Japan Manufacturing Industry, Tokyo, Ministry of Economy, Trade and Industry.

- $\quad$ METI (2010b), Industrial Structure Vision [provisional translation], Industrial Structure Council, Tokyo, Ministry of Economy, Trade and Industry.

- $\quad$ METI (2011), Challenges and Actions in Economic/Industrial Policies, Tokyo, Ministry of Economy, Trade and Industry.

- METI (2012), Vision of Economic Society - 'Maturity' and 'Diversity' [report summary], New Industrial Structure Committee of the Industrial Structure Council, Tokyo, Ministry of Economy, Trade and Industry.

- $\quad$ Miroudot, S., Lanz, R., and Ragoussis, A. (2009), ‘Trade in Intermediate Goods and Services’, OECD Trade Policy Working Papers.

- $\quad$ Nanto, D., Cooper, W., and Donnelly, J. (2011), Japan’s 2011 Earthquake and Tsunami Economic Effects and Implications for the United States, Washington, DC, Congressional Research Service.

- $\quad$ Nelson, R. (ed.) (1993), National Innovation Systems: A Comparative Analysis, New York and Oxford, Oxford University Press.

- $\quad$ Nezu, R. (2007), 'Industrial Policy in Japan’, Journal of Industry, Competition and Trade, 7(3-4), $229-43$.

- $\quad$ NIST (2013), ‘The Current State and Recent Trends of the US Manufacturing Industry', NIST Special Publication 1142, Washington, DC, National Institute of Standards and Technology.

- $\quad$ OECD (2013), Industrial Policies in a Changing World. Perspectives on Global Development, Paris, Organization for Economic Cooperation and Development.

- Okimoto, D. (1989), Between MITI and the Market: Japanese Industrial Policy for High Technology, Stanford, CA, Stanford University Press.

- $\quad$ OMB (2012), The President's Budget for the Fiscal Year 2013, Washington, DC, US Office of Management and Budget. 
- O'Sullivan, E. (2011), A Review of International Approaches to Manufacturing Research, Cambridge, University of Cambridge Institute for Manufacturing.

- $\quad$ Park, S.-H. (1989), 'Linkages between Industry and Services and Their Implications for Urban Employment Generation in Developing Countries’, Journal of Development Economics, 30(2), 359-79.

- $\quad$ PCAST (2012), Report to the President on Capturing Domestic Competitive Advantage in Advanced Manufacturing, Washington, DC, President's Council of Advisors on Science and Technology.

- $\quad$ Pilat, D., Cimper, A., Olsen, K., and Webb, C. (2008), 'The Changing Nature of Manufacturing in OECD Economies', in Staying Competitive in the Global Economy: Compendium of Studies on Global Value Chains, Paris, Organization for Economic Cooperation and Development.

- $\quad$ Pisano, G. P., and Shih, W. C. (2012), Producing Prosperity: Why America Needs a Manufacturing Renaissance, Boston, MA, Harvard Business Review Press.

- $\quad$ Rodrik, D. (2004), 'Industrial Policy for the Twenty-first Century’, paper prepared for UNIDO, John F. Kennedy School of Government, Boston, MA.

- $\quad$ Shi, Y., and Gregory, M. (1998), 'International Manufacturing Networks-To Develop Global Competitive Capabilities’, Journal of Operations Management, 16(2-3), 195-214.

- $\quad$ Simon, H. (2009), Hidden Champions of the Twenty-first Century: The Success Strategies of Unknown World Market Leaders, Berlin, Springer.

- $\quad$ Statistics Bureau (2013), Statistical Handbook of Japan 2013, Tokyo, Ministry of Internal Affairs and Communications.

- $\quad$ Stiglitz, J. E. (1996), 'Some Lessons from the East Asian Miracle’, The World Bank Research Observer, 11(2), 151-77.

- $\quad$ Sturgeon, T. (2002), 'Modular Production Networks: A New American Model of Industrial Organization', Industrial and Corporate Change, 11(3), 451-96.

- Kawakami, M. (2010), 'Global Value Chains in the Electronics Industry', in Global Value Chains in a Postcrisis World: A Development Perspective, Washington, DC, World Bank.

- Tassey, G. (2010), 'Rationales and Mechanisms for Revitalizing US Manufacturing R\&D Strategies', Journal of Technology Transfer, 35, 283-333.

- UNCTAD (2012), World Investment Report 2012: Towards a New Generation of Investment Policies, Geneva, United Nations Conference on Trade and Development.

- $\quad$ UNIDO (2011), Industrial Development Report 2011, Vienna, United Nations Industrial Development Organization.

- $\quad$ UNIDO (2013), The Industrial Competitiveness of Nations, Industrial Competitiveness Report. Vienna, United Nations Industrial Development Organization..

- $\quad$ US Office of Management and Budget (2012), The President's Budget for the Fiscal Year 2013, Washington, DC, US Office of Management and Budget.

- $\quad$ US Congress (2011a), Job Creation through Innovation Act, Washington, DC, US Congress.

- $\quad$ US Congress (2011b), Innovate America Act, Washington, DC, US Congress.

- $\quad$ US Department of Commerce (2004), Manufacturing in America. A Comprehensive Strategy to Address the Challenges of US Manufacturers, Washington, DC, US Department of Commerce.

- VDW (2013), The German Machine Tool Industry in 2012, German Machine Tool Builder Association, retrieved May 2013 from http://www.vdw.de/aktuelles/InterE_6943pub_deutsche_wzm_industrie1_2012.pdf

- Vitols, S. (1997), 'German Industrial Policy: An Overview’, Industry and Innovation, 4(1), 15-36.

- Wade, R. (1990), Governing the Market: Economic Theory and the Role of Government in East Asian Industrialization, Princeton, NJ, Princeton University Press.

- $\quad$ Wade, R. (2012), 'Return of Industrial Policy?’, International Review of Applied Economics, 26(2), $223-39$.

- Warwick, K. (2013), ‘Beyond Industrial Policy. Emerging Issues and New Trends’, OECD Science, Technology and Industrial Policy Papers No. 2. 
- Wessner, C. W., and Wolff, A. (eds) (2012), Rising to the Challenge: US Innovation Policy for Global Economy, Washington, DC, National Academy of Sciences Press.

- White House (2013), 'FACT SHEET: A Better Bargain for the Middle Class: Jobs’, press release, Office of the Press Secretary, White House, retrieved May 2013 from http://www.whitehouse.gov/the-pressoffice/2013/07/30/fact-sheet-better-bargain-middle-class-jobs 